\title{
Preferensi Konsumen Terhadap Atribut Produk Sayuran Organik di Kota Bandar Lampung
}

\section{Consumer Preferences for Product Attributes of Organic Vegetables in Bandar Lampung}

\author{
Sutarni*, Teguh Budi Trisnanto, dan Bina Unteawati \\ Program Studi Agribisnis Politeknik Negeri Lampung \\ *E-mail : sutarni@polinela.ac.id
}

\begin{abstract}
Specific Objectives of this research are: (1) analyze the attributes of organic agricultural products desired by consumers, (2) analyze the consumer preference for organic food product attributes, this research will be carried out in Bandar Lampung Supermarkets. The choice of location is done intentionally (purposive). Samples were taken as many as 30 respondents who consume organic agricultural products. The analytical method used, namely: Conjoint analysis, valuation of non-market value approach; contigensi valuation method (CVM). Research results show (1) A very important factor in the purchase of organic agricultural products is the first factor, namely: certificate of organic products labeled (for organic certification) reached $54.217 \%$, the second factor is the availability or stock of organic products in the Supermarket (17.419\%), the third factor is the packaging of organic agricultural products (14.237\%), and the last factor is the price of agricultural products (14.127), (2) Consumers prefer lower prices on organic products, organic agricultural products labeled (there is organic certificate of agencies or institutions), the availability or many stock of goods, and attractive packaging using sealed plastic and tidy,
\end{abstract}

Keywords: attributes, labels, preferences, conjoint, organic farming.

Disubmit : 05 Oktober 2017, Diterima : 01 Desember 2017, Disetujui :08 Desember 2017

\section{PENDAHULUAN}

Keuntungan pertanian organik bagi manusia dan lingkungan dalam jangka panjang adalah (1) meningkatkan kesuburan tanah dalam jangka panjang, (2) mengontrol serangan hama dan penyakit tanaman tanpa merusak lingkungan, (3) menjamin air tetap bersih dan aman, (4) menggunakan sumber daya yang dimiliki oleh petani, sehingga dapat mengurangi biaya input produksi pertanian, dan (5) menghasilkan pangan yang bergizi, pakan untuk hewan, dan tanaman berkualitas tinggi yang dapat dijual dengan harga layak (Susanto, 2002).

Pertanian organik saat ini makin populer, seiring dengan meningkatnya pendidikan, pendapatan, dan pengetahuan gizi masyarakat terhadap pola hidup sehat dan aman dari bahan-bahan kimia. Pertanian organik tidak hanya memberikan manfaat sehat dan aman bagi penggunanya, namun dapat memberikan manfaat bagi keberlanjutan sumber daya pertanian dan lingkungannya (Sustainability). Pertanian organik maupun semi organik di Provinsi Lampung belum berkembang secara pesat. Input produksi yang digunakan dalam usahatani masih berasal dari bahan-bahan kimia. $100 \%$ petani menggunakan pupuk kimia dan pestisida kimia dalam usahatani. Penerapan pupuk organik dan pestisida nabati yang digunakan untuk usahatani 
hanya mencapai 10-25\% (Sutarni, 2010). Hal ini menunjukkan bahwa secara umum usahatani yang diterapkan oleh petani masih mengutamakan bahan-bahan kimia dalam budidaya pertanian dan belum mengembangkan budidaya secara organik di Provinsi Lampung.

Perkembangan lahan pertanian organik di Indonesia sekitar 225.062,65 ha (SPOI, 2011 dalam Muljaningsih, S. 2011). Konsumsi hasil pertanian organik juga mengalami peningkatan, hal ini dapat ditunjukkan munculnya outlet-outlet dan restouran organic. Di Jakarta, Bandung, dan Surabaya makanan organic (organic food) sudah mulai populer. Hal ini menunjukkan permintaan konsumen dan kesadaran masyarakat terhadap pertanian organik memiliki peluang pasar untuk dikembangkan. Produk organik memiliki harga lebih mahal karena investasi digunakan untuk praktek pertanian organik juga yang tinggi pula (Muljaningsih, S. 2011).

Target pasar produk organik yang memungkinkan saat ini masih pada pasar modern yaitu supermarket. Jenis-jenis produk yang dijual cukup beragam yaitu; produk sayuran, buah, biji-bijian seperti beras organik, biofarmaka, dan lain-lain. Belum berkembangnya pertanian organik di Provinsi Lampung perlu dicari solusinya, mengingat permintaan produk pertanian organik di Kota Bandar Lampung makin meningkat. Penilaian ekonomi (Economic Valuation/EV) pertanian organik tentunya sangat penting dan diperlukan untuk menentukan kebijakan pada masa yang datang. Economic Valuation merupakan pengukuran nilai dari barang atau jasa yang dihasilkan oleh sumber daya alam dan lingkungan baik yang dapat dikonsumsi baik langsung maupun tidak langsung, atau jasa lingkungan yang memberikan manfaat dalam bentuk lain seperti ketenangan, keindahan, kesehatan, keamanan, keberlanjutan (sustainability) dan lain-lain. Economic valuation bertujuan untuk membantu penentu kebijakan dalam pengambilan keputusan untuk menduga efisiensi ekonomi (economic efficiency) dari pemanfaatan yang mungkin dilakukan (Fauzi, A., 2006).

Penilaian ekonomi pertanian organik dapat dilakukan dengan cara yaitu: pendekatan dari sudut konsumen dapat dianalisis melalui preferensi konsumen dan Willingness to pay (WTP) atau kemauan konsumen untuk membayar produk pertanian organic. Pendekatan tersebut dapat menjadi pertimbangan dalam menentukan kebijakan pertanian berkelanjutan pada masa yang datang. Penelitian preferensi konsumen terhadap pertanian organic telah dilakukan diantaranya: Astari (2012) menyatakan bahwa atribut kesegaran, ketersediaaan, harga, label dan kemasan menjadi pertimbangan kosumen dalam pembelian kangkung organik, sedangkan preferensi konsumen dalam pembelian kangkung organik adalah kangkung organik yang segar, ketersediaannya selalu ada (setiap hari), harganya kurang dari Rp3.000,00 per ons, terdapat label organik yang besar dan jelas, dan menggunakan kemasan plastik tertutup dan rapi. Damayanty, Rita (2009) Menguraikan harga merupakan atribut terpenting oleh konsumen, oleh karena itu produsen harus mempertimbangkan untuk menyesuaikan harga dengan keinginan konsumen wortel organik. Penyesuaian harga dapat dilakukan meninjau kembali biaya produksi. Selanjutnya, Muljaningsih, S., 2011 menyatakan bahwa preferensi konsumen terhadap beras, buah, dan sayuran organic adalah baik untuk kesehatan, tetapi keluhannya produk organic lebih mahal. Preferensi konsumen tidak dibatasi oleh usia dan pendidikan. Harga merupakan atribut terpenting oleh konsumen. Menurut Suardika, I.M.P., dkk (2014) menyatakan pola hubungan positif terdapat pada jalur motivasi, persepsi, pembelajaran, sikap, produk, promosi dan lokasi terhadap keputusan pembelian sayuran organik. Hal ini berarti semakin memenuhi atau semakin baik aspek - aspek tersebut maka keputusan pembelian sayuran organik yang terjadi akan semakin tinggi, sebaliknya semakin kurang memenuhi/baik aspek - aspek tersebut maka keputusan pembelian sayuran organik yang terjadi akan semakin menurun.

Berdasarkan uraian dan penelitian sebelumnya, permasalahan yang dihadapi dalam penerapan pertanian organik di Provinsi Lampung adalah harga produk organik lebih mahal, konsumen produk pangan organik belum luas pada masyarakat secara umum, tapi kecenderungannya masih menjangkau pada segmen pasar masyarakat yang memiliki pendapatan menengah ke atas, berpendidikan tinggi, dan memiliki 
pengetahuan tentang kesehatan dan lingkungan hidup yang luas. Beragamnya karakteristik dan keinginan konsumen terhadap pangan organik, sehingga perlu diamati minat dan perbedaan kecenderungannya/preferensi konsumen dalam memilih atribut-atributnya serta seberapakah besarnya kemauan kosumen membayar produk organik tersebut. Tujuan dari penelitian ini adalah melakukan penilaian ekonomi (Economic Valuation/EV) pertanian organik untuk mendorong berkembangnya praktek pertanian berkelanjutan di Provinsi Lampung.

\section{METODE PENELITIAN}

Penelitian akan dilaksanakan selama 4-6 bulan pada bulan Agustus sampai bulan November. Penelitian ini akan dilaksanakan di Kota Bandar Lampung Provinsi Lampung. Pemilihan lokasi dilakukan secara sengaja (Purposive), dengan pertimbangan bahwa di Kota Bandar Lampung terdapat swalayan yang menjual produk pangan organic dan terdapat konsumen swalayan yang mengkonsumsi produk organik.

Populasi penelitian ini adalah konsumen swalayan yang membeli produk pertanian organik di 3 swalayan/supermarket di Kota Bandar Lampung. Jumlah responden yang diambil sebanyak 30 responden. Pemilihan sampel merujuk untuk tujuan analisis sebab akibat yang mensyaratkan jumlah sampel minimal sebanyak 30 sampel (Sugiarto, D. Siagian, dkk, 2003)

Tabel 1. Jenis atribut dan level terhadap produk pertanian organik

\begin{tabular}{llcc}
\hline No. & $\begin{array}{c}\text { Atribut produk pertanian } \\
\text { organik }\end{array}$ & Level \\
\hline 1. & Harga & Tinggi & Rendah \\
2. & Sertifikat organik & Belabel organik & Tidak berlabel organik \\
3. & Kemasan/packaging & Menarik & Kurang menarik \\
5. & Ketersediaan/stok & Banyak & Sedikit \\
\hline
\end{tabular}

Pengumpulan data dilakukan melalui survei, yaitu penelitian yang mengambil sampel dari populasi dan menggunakan kuisioner sebagai alat pengumpulan data yang pokok. Jenis data dibedakan menjadi 2 yaitu data primer dan data sekunder. Data primer diperoleh melalui wawancara langsung kepada responden dengan menggunakan kuisioner/daftar pertanyaan yang telah dipersiapkan terlebih dahulu. Data sekunder diperoleh dari berbagai instansi terkait.

Analisis yang digunakan untuk menjawab tujuan penelitian ke (1) dan ke (2), adalah: Analisis Conjoint. Menurut Ghozali, I (2006) menyatakan analisis conjoint merupakan teknik yang khusus digunakan untuk memahami bagaimana responden mengembangkan preferensi suatu produk atau jasa. Secara umum model dasar model dasar analisis conjoint dapat dirumuskan secara matematis (Firdaus, 2004 dalam Sayekti, W.D., 2009).

Tabel 2. Stimuli atribut yang terbentuk pada proses konjoin

\begin{tabular}{ccccc}
\hline $\begin{array}{c}\text { Card } \\
\text { Stimuli }\end{array}$ & Harga & Sertifikat organik & $\begin{array}{c}\text { Ketersediaan/ } \\
\text { Stok }\end{array}$ & $\begin{array}{c}\text { Kemasan/ } \\
\text { packaging }\end{array}$ \\
\hline 1 & Rendah & Berlabel & Sedikit & Kurang menarik \\
2 & Tinggi & Tidak berlabel & Sedikit & Menarik \\
3 & Rendah & Berlabel & Sedikit & Menarik \\
4 & Rendah & Tidak berlabel & Banyak \\
5 & Tinggi & Tidak berlabel & Sedikit & Kurang menarik \\
6 & Tinggi & Berlabel & Banyak & Menarik \\
7 & Rendah & Tidak berlabel & Banyak & Kurang menarik \\
8 & Tinggi & Berlabel & Banyak & Kurang menarik \\
\hline
\end{tabular}

Sumber: Data hasil pengolahan stimuli pada program SPSS, tahun 2014 
Langkah-langkah analisis conjoint dalam penelitian pertanian organik ini adalah menentukan faktor atau atribut spesifik dan level (bagian-bagian dari faktor) produk pertanian organik. Untuk mengoperasionalkan atribut produk organik peneliti mengembangkan 2 faktor dengan masing-masing level (Tabel 1), mendesain stimulasi (Tabel 2). Mengumpulkan pendapat responden terhadap setiap stimulasi yang ada, dan melakukan proses conjoint dan menentukan predictive accuracy (ketepatan prediksi). Proses analisis coinjoint dengan program SPSS dilakukan dua tahap yaitu: (a) Membuat stimuli dengan prosedur orthogonal, dan (b) Melakukan proses conjoint dan penyusunan laporan penelitian

\section{HASIL DAN PEMBAHASAN}

Karakteristik Responden. Konsumen swalayan yang dijadikan sampel pada penelitian ini adalah konsumen yang berbelanja di Swalayan Chandra Mall Bumi Kedaton, Chandra Tanjung Karang, dan Hypermart. Jumlah sampel diambil sebanyak 30 orang dengan pertimbangan untuk kebutuhan analisis statistik dengan hubungan sebab akibat mensyaratkan sampel minimal 30 sampel.

Umur responden konsumen produk organik di swalayan Kota Bandar Lampung yaitu rata-rata berusia 35,53 tahun, dengan umur terendah 21 tahun dan umur tertinggi 64 tahun. Usia responden penelitian ini tergolong pada usia produktif yaitu usia 15-64 tahun. Responden penelitian memiliki pendidikan cukup tinggi dan telah melanjutkan pada perguruan tinggi. Persentase pendidikan responden dapat dilihat pada Tabel 3.

Tabel 3. Tingkat Pendidikan Responden

\begin{tabular}{cccc}
\hline No. & Jenjang pendidikan & Jumlah & \% \\
\hline 1. & SLTA & 3 & 10 \\
2. & D1 & 9 & 30 \\
3. & S1 & 18 & 60 \\
\hline & Jumlah & 30 & 100 \\
\hline
\end{tabular}

Tabel 3 menunjukkan bahwa pendidikan responden produk pertanian organik dalam penelitian ini sebagian besar berpendidikan tinggi yaitu sebanyak 18 orang berpendidikan Sarjana (S1) atau sebanyak $60 \%$, dan hanya 3 orang atau 10\% yang berpendidikan SLTA. Hal ini menunjukkan bahwa semakin tinggi pendidikan seseorang memberi indikasi wawasan dan pengetahuan tentang kelebihan-kelebihan pertanian organik yang ramah terhadap lingkungan, memiliki nutrisi yang tinggi, dan aman untuk dikonsumsi, sehingga tingkat pendidikan seseorang akan mempengaruhi preferensi seorang konsumen dalam memutuskan untuk membeli produk-produk organik.

Jenis pekerjaan responden penelitian ini cukup beragam yaitu dari ibu rumah tangga, wiraswasta, maupun Pengawai Negeri Sipil (PNS). Jumlah responden berdasarkan jenis pekerjaaannya dapat dilihat pada Tabel 4.

Tabel 4. Jumlah responden berdasarkan jenis pekerjaaannya

\begin{tabular}{|c|c|c|c|}
\hline No. & Jenis pekerjaan & Jumlah & $\%$ \\
\hline 1. & Ibu Rumah Tangga & 13 & 43,33 \\
\hline \multirow[t]{7}{*}{2.} & Ibu Berkerja & & 56,67 \\
\hline & a) Pengawai BUMN & 1 & 3,33 \\
\hline & Pengawai Swasta & 3 & 10,00 \\
\hline & PNS & 3 & 10,00 \\
\hline & d) Pengawai honorer & 2 & 6,67 \\
\hline & e) Wiraswasta & 8 & 26,67 \\
\hline & Jumlah & 30 & 100 \\
\hline
\end{tabular}

Tabel 4 menunjukkan bahwa responden produk pertanian oragik di daerah penelitian sebagian besar adalah ibu-ibu yang memiliki pekerjaan yaitu mencapai 27 orang atau sebanyak 56,67\%, hal ini 
mengindikasikan bahwa perempuan yang memiliki pekerjaan sendiri memiliki potensi keuangan sendiri, sehingga preferensi terhadap konsumsi untuk produk pertanian organik pun juga tinggi. Namun demikian, ibu rumah tangga juga relatif tinggi pula mencapai $43,33 \%$, hal ini diduga ibu-ibu rumah tangga juga memiliki wawasan dan pengetahuan yang tinggi terhadap produk pertanian organik. Hal ini dapat dilihat dari latar belakang pendidikan responden yang sebagian besar adalah berpendidikan tinggi. Meskipun ibu rumah tangga tidak memiliki keuangan sendiri tetap melakukan pembelanjaan terhadap produk pertanian organik.

Presepsi Konsumen terhadap Produk Pertanian Organik. Pertanian organik adalah teknik budidaya pertanian yang mengandalkan bahan-bahan alami tanpa menggunakan bahan-bahan kimia sintetis. Tujuan utama pertanian organik adalah menyediakan produk-produk pertanian terutama bahan pangan yang aman bagi kesehatan produsen dan konsumennya serta tidak merusak lingkungan. Gaya hidup sehat saat ini telah melembaga secara international yang mensyaratkan bahwa produk pertanian beratribut aman dikonsumsi (food safety atributes), kandungan nutrisi tinggi (nutritriol attributes), dan ramah lingkungan (eco-labelling atributes). Prefernsi konsumen seperti itu menyebabkan permintaan produk organik dunia meningkat (Litbang Pertanian, 2002). Menurut penelitian Gani, AA. (2008) menyatakan pendapatan petani kopi organik lebih besar dibandingkan dengan pendapatan petani kopi an oragnik, sedangkan harga jual produk organik lebih tinggi dibandingkan dengan harga produk anorganik. Selanjutnya Suhartini (2004) menyatakan bahwa benefit cost ratio (BCR) dan Sosial Benefit cost ratio (SBCR) usahatani beras semi organik lebih tinggi dari pada usahatani beras non organik. Dilihat dari kegiatan usahatani pertanian organik menguntungkan bagi pelaku usaha, hal ini berkaitan erat dengan presepsi an preferensi konsumen terhadap produk organik tersebut.

Presepsi konsumen pada penelitian ini yang berpendapat bahwa produk pertanian organik memiliki atribut aman dikonsumsi, kandungan nutrisi tinggi, dan ramah lingkungan dapat dilihat pada Tabel 5.

Tabel 5. Presepsi konsumen terhadap produk pertanian organik

\begin{tabular}{|c|c|c|c|}
\hline No. & Keterangan : Atribut produk organik & Jumlah (orang) & $\%$ \\
\hline \multirow[t]{3}{*}{1} & a. Ramah lingkungan & 28 & 93,33 \\
\hline & $\begin{array}{l}\text { b. Sama dengan dengan produk non } \\
\text { organik }\end{array}$ & 2 & 6,67 \\
\hline & c. Tidak ramah lingkungan & 0 & 0 \\
\hline \multirow[t]{3}{*}{2.} & a. Kandungan nutrisi tinggi & 27 & 90 \\
\hline & $\begin{array}{l}\text { b. Sama dengan dengan produk non } \\
\text { organik }\end{array}$ & 3 & 10 \\
\hline & c. Randah kandungan nutrisi & 0 & \\
\hline \multirow[t]{3}{*}{3} & a. Aman untuk dikonsumsi & 28 & 93,33 \\
\hline & $\begin{array}{l}\text { b. Sama dengan dengan produk non } \\
\text { organik }\end{array}$ & 2 & 6,67 \\
\hline & c. Tidak aman dikonsumsi & 0 & 0 \\
\hline
\end{tabular}

Presepsi konsumen memiliki nilai yang baik terhadap produk pertanian organik. Jumlah konsumen yang menilai bahwa produk pertanian organik memiliki kelebihan dalam penerapan sistem produksi yang berprinsip ramah terhadap lingkungan dan memiliki keamanan untuk dikonsumsi karena dalam proses produk menggunakan bahan-bahan kimia baik pupuk maupun pestisida cukup tinggi yaitu mencapai 93,33\% dan sisanya $6,67 \%$ menilai sama dengan produk non organik. Jumlah konsumen yang memiliki presepsi bahwa produk pertanian organik memiliki kandungan nutrisi tinggi mencapai $90 \%$ dan sisanya $10 \%$ menilai produk organik sama dengan produk non organik.

Preferensi Konsumen terhadap Produk Pertanian Organik. Preferensi konsumen terhadap produk pertanian organik digunakan pendekatan analisis statistik multivariate analisis statistik conjoint, dengan 4 
atribut dan masing-masing memiliki 2 level. Atribut dan level masing-masing atribut dapat dilihat pada Tabel 6.

Tabel 6. Atribut dan level/subatribut produk pertanian organik

\begin{tabular}{ccc}
\hline No. & Atribut & Level/subartribut \\
\hline 1. & Harga produk organik & Tinggi \\
& & Rendah \\
\hline 2. & Sertifikat organik & Berlabel organik \\
& & Tidak berlabel oragnik \\
\hline 3. & Ketersediaan/stok & Banyak \\
& Sedikit \\
\hline 4. & Kemasan/packing & Menarik \\
& & Kurang menarik \\
\hline
\end{tabular}

Berdasarkan atribut dan level/subatribut yang disusun dalam penelitian ini memiliki kemungkinan kombinasi sebanyak $(2 \times 2 \times 2 \times 2)=16$ stimuli. Secara teoritis seorang responden harus menilai 16 atribut produk pertanian organik. Namun hal ini cenderung akan menyulitkan. Oleh karena itu, pada penelitian ini untuk menyusun stimuli tersebut digunakan prosedur orthogonal dengan menggunakan software SPSS versi 16. Adapun hasil dari analisis tersebut diperoleh 8 stimuli atau kombinasi pilihan bagi konsumen dalam memilih atribut produk pertanian organik. Prosedur orthogonal stimuli untuk preferensi konsumen terhadap produk pertanian organik dapat dilihat pada Tabel 7.

Tabel 7. Prosedur orthogonal stimuli untuk preferensi konsumen terhadap produk pertanian organik

\begin{tabular}{ccccc}
\hline Stimuli & Harga & Sertifikat organik & $\begin{array}{c}\text { Ketersediaan/ } \\
\text { Stok }\end{array}$ & $\begin{array}{c}\text { Kemasan/ } \\
\text { packaging }\end{array}$ \\
\hline 1 & Rendah & Berlabel & Sedikit & Kurang menarik \\
2 & Tinggi & Tidak berlabel & Sedikit & Menarik \\
3 & Rendah & Berlabel & Sedikit & Menarik \\
4 & Rendah & Tidak berlabel & Banyak & Menarik \\
5 & Tinggi & Tidak berlabel & Sedikit & Kurang menarik \\
6 & Tinggi & Berlabel & Banyak & Menarik \\
7 & Rendah & Tidak berlabel & Banyak & Kurang menarik \\
8 & Tinggi & Berlabel & Banyak & Kurang menarik \\
\hline
\end{tabular}

Selanjutnya, responden diminta untuk memberikan pendapat untuk memilih mengenai ke delapan stimuli tersebut. Hasil analisis conjoint tentang preferensi konsumen terhadap atribut produk pertanian organik dapat dilihat pada Tabel 8. Hasil output SPSS diperoleh angka konstan sebesar 23,704. Angka konstan ini digunakan sebagai dasar untuk menghitung nilai utility dari faktor harga, label, ketersediaan/stok, dan kemasan/packaging. Jadi utility adalah selisih antara rata-rata faktor tertentu dengan nilai konstannya. Jika selisih positif maka responden kurang suka pada stimuli produk tersebut, sebaliknya jika selisih negatif maka respon suka dengan stimuli produk tersebut, hal ini disebabkan urutan angka 1 (sangat disukai) dan sedangkan angka 8 (tidak disukai) (Ghozali, I. 2006).

Secara umum responden atau konsumen menilai atau berpendapat bahwa faktor yang sangat penting dalam pembelian produk pertanian organik adalah adanya sertifikat organik pada label produk mencapai $54,217 \%$, faktor kedua yaitu ketersediaan atau stok produk organik di Swalayan (17,419\%), faktor ketiga yaitu kemasan/packaging pada produk pertanian organik $(14,237 \%)$, dan faktor terakhir yaitu harga pada produk pertanian $(14,127 \%)$. 
Tabel 8. Hasil output : Penilaian umum preferensi konsumen agregat terhadap beberapa atribut produk pertanian organik

\begin{tabular}{ccll}
\hline $\begin{array}{c}\text { Faktor Kepentingan } \\
\text { (Averaged Importance })\end{array}$ & $\begin{array}{c}\text { Utilitas } \\
(\text { utility } \\
\text { Estimate })\end{array}$ & \multicolumn{1}{c}{ Atribut/faktor } & \multicolumn{1}{c}{ Preferensi } \\
\hline 14,127 & 0,859 & $\begin{array}{l}\text { Harga produk organik } \\
\text { Tinggi } \\
\text { Rendah }\end{array}$ & Harga rendah \\
\hline 54,217 & $-0,859$ & Sertifikat organik & Kemasan berlabel \\
& $-0,969$ & Berlabel organik & organik (terdapat \\
& 0,969 & Tidak berlabel organik & sertifikat organik) \\
\hline 17,419 & $-0,750$ & Kertersediaan/stok & Ketersedian/stok barang \\
& 0,750 & Sedikit & banyak \\
& & Kemasan & Kemasan menarik \\
& $-0,859$ & Menarik & \\
\hline 14,237 & 0,859 & Kurang menarik & \\
\hline Constant & 23,704 & & \\
\hline Person's R $=0,716$ & & Signifikasi (significance) $=0,023$ \\
\hline Kendall' Tau $=0,143$ & & Signifikasi (significance) $=0,310$ \\
\hline
\end{tabular}

Secara umum responden lebih menyukai harga rendah pada produk pertanian organik, hal ini dapat dilihat dari utility harga rendah bernilai negatif sebesar $-0,859$. Keputusan responden dalam membeli produk organik masih dipengaruhi oleh faktor harga produk. Hal ini seiring dengan hukum ekonomi mengenai harga yang menyatakan bahwa semakin tinggi harga maka jumlah barang yang dibeli oleh konsumen semakin sedikit, sebaliknya semakin rendah harga barang, maka jumlah barang yang dibeli oleh konsumen semakin banyak. Penelitian ini juga diperkuat oleh penelitian Damayanty (2009) tentang analisis preferensi konsumen wortel organik amani Masrtra di Foodmart Ekalokasari yang menyatakan bahwa harga merupakan atribut yang terpenting dalam membeli wortel organik. Wortel yang diinginkan oleh konsumen adalah harganya murah. Kesediaan responden produk pertanian organik di Kota Bandar Lampung telah ditunjukkan oleh kemauan konsumen membeli produk organik (willingness to buy) tersebut, namun jika harga produk organik lebih rendah maka dimungkinkan volume penjualan produk pertanian organik akan meningkat. Oleh karena itu, kerja sama dengan antara swalayan penjual produk organik dengan produsen organik menjadi penting, sehingga produsen mampu memproduksi produk organik dengan biaya produksi budidaya organik yang rendah.

Responden lebih menyukai produk pertanian organik berlabel organik atau produk organik yang telah memiliki sertifikat organik yang dicantumkan pada label dan kemasannya, dengan nilai utility bernilai negatif sebesar $-0,969$. Sertifikat organik menjadi penting bagi konsumen dalam memutuskan membeli produk organik, karena sertifikat merupakan jaminan atau garansi yang menunjukkan bahwa produk yang dibeli merupakan produk yang diproduksi dengan memperhatikan keramahan terhadap lingkungan, memiliki keamanan pangan bebas dari bahan-bahan kimia baik pestisida kimia maupun pupuk kimia, serta mensuplai bahan pangan yang memiliki kandungan nutrisi tinggi. Hasil penelitian ini sejalan dengan penelitian Astari (2012) menyatakan bahwa atribut kesegaran, ketersediaaan, harga, label dan kemasan menjadi pertimbangan kosumen dalam pembelian kangkung organik, sedangkan preferensi konsumen dalam pembelian kangkung organik salah satunya adalah terdapat label organik yang besar dan jelas.

Responden lebih menyukai produk pertanian organik yang banyak stoknya, dengan nilai utility bernilai negatif sebesar $-0,750$. Stok yang banyak memudahkan seorang konsumen melakukan banyak 
pilihan terhadap produk. Hal ini sesuai dengan penelitian Damayanty (2009) dan Astari (2012) yang menyatakan bahwa kertesediaan menjadi faktor yang penting dalam mepengaruhi konsumen dalam pembelian produk organik. Konsumen lebih menyukai kertersediaan produk organik yang selalu ada setiap hari dengan jumlah banyak.

Kemasan produk pertanian organik yang dikemas rapi lebih disukai responden dengan nilai utility bernilai negatif sebesar $-0,859$. Kemasan yang diterapkan di swalayan yang dilakukan dipenelitian ini yaitu sayuran dikemas dengan plastik sehingga produk kelihatan rapi dan menarik. Hasil penelitian ini sejalan dengan penelitian Astari (2012) yang menyatakan bahwa preferensi konsumen dalam pembelian kangkung organik adalah salah satunya terdapat label organik yang besar dan jelas, dan menggunakan kemasan plastik tertutup dan rapi. Begitu halnya pendapat Windani, Isna (2009) menyatakan atribut beras organik mempunyai korelasi positif terhadap preferensi konsumen adalah kemasan beras organik.

Keakurasian peridiksi (predictive accuracy) diukur dengan korelasi Pearson yang besarnya adalah 0,713 yang berbeda nyata pada taraf kepercayaan lebih kecil dari 0,05. Namun berdasarkan keakurasian peridiksi diukur dengan korelasi Kendall besarnya adalah 0,143 tidak berbeda nyata pada taraf kepercayaan 0,05. Hasil pengujian berdasarkan korelasi Pearson menunjukkan bahwa pendapat dari 30 responden pada penelitian ini dapat diterima dalam mengambarkan keinginan populasi untuk membeli produk pertanian organik yang memiliki ciri-ciri produk pertanian organik memiliki produk berlabel organic (sertifikat organic), kersediaan atau stok barang yang banyak, kemasan yang menarik dengan menggunakan plastic yang rapi, dan harga yang rendah sehingga terjangkau oleh konsumen dengan berbagai tingakatan masyarakat.

\section{KESIMPULAN DAN SARAN}

Berdasarkan hasil dan pembahasan maka dapat disimpulkan bahwa faktor yang sangat penting dalam pembelian produk pertanian organik adalah faktor pertama, yaitu: sertifikat produk yang berlabel organik (adanya sertifikat organik) mencapai 54,217\%, faktor kedua yaitu ketersediaan atau stok produk organik di Swalayan (17,419\%), faktor ketiga yaitu kemasan pada produk pertanian organik (14,237\%), dan faktor terakhir yaitu harga pada produk pertanian $(14,127 \%)$.

Konsumen lebih menyukai harga rendah pada produk pertanian organik, produk pertanian organik yang mencantumkan label organik (adanya sertifikat organik dari lembaga atau institusi), ketersediaan atau stok barang yang banyak, dan kemasan yang menarik dengan menggunakan plastik tertutup dan rapi. Kemudian, penjual produk organik harus memperhatikan sertifikat organik terhadap produk yang akan dijual, karena konsumen menganggap bahwa jaminan produk organik yang dijual oleh produsen adalah sertifikat organik yang dicantumkan dalam label dan kemasan produk pertanian organik. Selain itu, pihak swalayan dan produsen organik harus memperhatikan atribut-atribut yang diinginkan oleh konsumen seperti sertikat organik harus ada, ketersedian atau stok harus banyak, kemasan harus menarik, dan harga yang dapat menjangkau konsumen.

\section{DAFTAR PUSTAKA}

Astari, H.M. 2012. Preferensi konsumen Swalayan Terhadap Kangkung Organik di Purwokerto Kabupaten Banyumas. Tesis Pasca Sarjana Sosial Ekonomi/Agribisnis Universitas jenderal Soedirman. Semarang.

Damayanty, R. 2009. Analisis Prefrensi Konsumen Wortel Organik Amani Mastra di Foodmart Ekalokasari. Skripsi Manajemen Agribisnis Fakultas Pertanian IPB. Bogor.

Fauzi, A. 2006. Ekonomi Sumber Daya Alam dan lingkungan. PT Gramedia Pustaka Utama. Jakarta. 
Ghozali, I. 2006. Aplikasi Analisis Multivariate dengan program SPSS. Badan Penerbit Universitas Diponegoro. Semarang.

Gani, A.A., 2008. Analisis Koparatif Pendapatan Kopi Organik dan Petani Kopi Anorganik di Dataran Tinggi Gayo Nanggroe Aceh Darussalam. Jurnal Esai, Vol. 2 No. 2 Juli 2008. Jurusan Ekonomi dan Bisnis Polinela. Bandar Lampung.

Muljaningsih, S. 2011. Preferensi Konsumen Dan Produsen Produk organic di Indonesia. Jurnal Wacana.Vol. 14, No 4 2011. PS Kajian Lingkungan dan Pembangunan Program Pascasarjana Universitas Brawijaya. Semarang.

Sutarni. 2010. Dampak Introduksi Teknologi Benih Unggul Hibrida terhadap efsiensi padi sawah di Kabupaten Lampung Tengah Propinsi Lampung. Tesis Pasca Sarjana Universitas Lampung. Bandar Lampung.

Sayekti, D.W. 2009. Preferensi Konsumen Terhadap Bihun di Kota Bandar Lampung dan Metro. Jurnal Sosio Ekonomika Vol. 15 No. 2 Desember 2009. Bandar Lampung.

Sugiarto, D. Siagian, L.S. Sunarto dan D.S. Oetomo. 2003. Teknik Sampling. Gramedia Pustaka Utama. Jakarta.

Susanto, Rachman. 2002. Penerapan Pertanian Organik, Pemasyarakatan dan Pengembangannya. Kanisius. Yogyakarta.

Suardika, I.M.P.. Ambarawati, I.G.A.A.,. Sukaatmadja, I.P., 2014. Analisis Perilaku Konsumen terhadap Keputusan Pembelian Sayur Organik CV Golden Leaf Farm Bali. Jurnal Manajemen Agribisnis Vol. 2, No. 1, Mei 2014 ISSN: 2355-0759. Studi Magister Agribisnis, Program Pascasarjana, Universitas Udayana.

Suhartini.,2008. Sustainable organic rice System In Sragen Malang. www.searce.org/web/elibrary//thesis-abstrak.suhartini.pdf-filiphina.mirip.

Widani, Isna. 2009. Preferensi konsumen Terhadap Beras Organik di kota Yogyakarta. Tesis Pasca Sarjana Ekonomi Pertanian UGM. Yogyakarta. 